\title{
Morphological characterization of Ampelomyces spp., a hyperparasite of Bhendi (Abelmoschus esculentus (L.) Moench) powdery mildew
}

\author{
K. Athira ${ }^{1^{*}}$, N. Ragupathi ${ }^{2}$ and T. Raguchander ${ }^{3}$ \\ ${ }^{1}$ Vanavarayar Institute of Agriculture, Manakkadavu, Pollachi- 642103 (Tamil Nadu), INDIA \\ ${ }^{2}$ Directorate of Students Welfare (DSW), Tamil Nadu Agricultural University, Coimbatore-641003(Tamil Nadu), \\ INDIA \\ ${ }^{3}$ Department of Plant Pathology, AC and RI, Valavachanur, Thiruvannamalai- 606753(Tamil Nadu), INDIA \\ *Corresponding author. E-mail: athirakk@gmail.com
}

Received: August 21, 2016; Revised received: May 4, 2017; Accepted: September 12, 2017

\begin{abstract}
Ampelomyces is a naturally occurring hyperparasite on powdery midews. Survey was conducted in major bhendi (Abelmoschus esculentus (L.) Moench) growing districts of Tamil Nadu during June 2014 to assess the incidence of powdery mildew and to collect different isolates of Ampelomyces spp. The results of the survey revealed that the disease incidence ranged from 15.54 to $63.45 \%$. Ten isolates of Ampelomyces spp. were collected from surveyed areas of powdery mildew. Isolation of Ampelomyces spp. was done from powdery mildew infected bhendi leaf parasitized by Ampelomyces spp. using tissue segment method. All the isolates were identified by their morphological characters. The colour of the colonies in various medium was brownish black to greenish white. Most of the isolates showed radial and fluffy growth pattern with raised growth. The pycnidia of different isolates of Ampelomyces varied in their shape and were mostly ovoid, ellipsoid, cylindrical, pyriform to globose in shape. The size of pycnidia varied from $29.2-72.5 \times 22.4-43.1 \mu \mathrm{m}$. The number of pycnidia was found to be more in isolates viz., TNAU-AQ101 and TNAU-AQ103. Pycnidiospores are hyaline, unicellular and guttulate in shape. The pycnidial production was higher in TNAU-AQ101 and TNAU-AQ103. Application of agrochemicals is one of the oldest and most effective methods to manage powdery mildew disease. However, incessant use of these agrochemicals has many demerits such as development of resistance to pathogens, residual toxicity and environmental pollution. Hence, search for an alternative means for disease management is envisaged. The genus Ampelomyces are the major antagonists as an alternative of Erysiphales fungi being a significant group of phytopathogens.
\end{abstract}

Keywords: Ampelomyces, Bhendi,, Erysiphales, Hyperparasite, Pycnidia, Tissue segment method

\section{INTRODUCTION}

Okra (Abelmoschus esculentus (L.) Moench) belonging to the family malvaceae popularly known as Bhendi or Ladies finger is one of the most delicious and important vegetable crops grown throughout the country. It is grown for its tender green pods in tropics, subtropics and warmer parts of temperate region (Maurya et al., 2013).

A number of biotic and abiotic factors are responsible for the low yield of Okra. Among the biotic factors, powdery mildew caused by Erysiphe cichoracearum DC is a destructive disease worldwide (Glawe, 2008) which causes an yield losses of 20 to $40 \%$ (Agrios, 2005 ) or 17 to $86.6 \%$ (Younes and Abo-Elyousr, 2014). The disease affects all stages of growth causing premature defoliation. Erysiphe cichoracearum, the powdery mildew pathogen of okra is causing the most widespread disease generally favoured by dry atmospheric and soil conditions (Yarwood, 1957).

Control of powdery mildews relies mainly on the use of chemical fungicides, yet intensive use of these can result in the accumulation of residual chemicals that are potentially hazardous to humans and the environment. In order to reduce the use of chemical pesticides, alternative methods for controlling powdery mildews have been studied, including the use of microbial biocontrol agents (Paulitz and Bélanger, 2001).

Ampelomyces quisqualis Ces. is a hyperparasitic fungi which can parasitize hyphae, conidiophores and chasmothecia of more than 64 different species of powdery mildew fungi, including the genera Brasilomyces, Erysiphe, Leveillula, Microsphaera, Phyllactinia, Podosphaera, Sphaerotheca and Uncinula (Kiss, 1998). The mycelial development of A. quisqualis suppresses both asexual and sexual sporulation of the powdery mildew pathogen (Sundheim and Krekling, 1982).

Due to its wide host range, the mycoparasite is a highly promising candidate for biological control. A. quisqualis best typifies the potential of mycoparasites, as it is highly specific to powdery mildews, does not produce any toxic metabolites and can easily be mass-produced in vitro.

With this background, the present study was carried out envisaging the following objectives i) to assess the incidence of powdery mildew in major bhendi 
(A. esculentus (L.) Moench) growing districts of Tamil Nadu and to collect different isolates of Ampelomyces spp. ii) morphological characterization of Ampelomyces spp.

\section{MATERIALS AND METHODS}

Survey for the incidence of powdery mildew of bhendi in Tamil Nadu: Survey was conducted in major bhendi (A. esculentus (L.) Moench) growing districts of Tamil Nadu viz., Coimbatore, Madurai, Dharmapuri, Dindigul, Trichy, Erode, Salem, Tirupur, Theni and Cuddalore for assessing the incidence of powdery mildew of bhendi during the month of June, 2014. In each district, three villages were randomly chosen and in each village 3 farmer's fields were selected and in each farmers field, at three places 20 plants were selected at random and Per cent Disease Index (PDI) was worked out as per the standard grade chart (Ravinder Reddy, 1982).

Disease score chart for powdery mildew

\begin{tabular}{ll}
\hline Grade & Description (\% leaf area infected) \\
\hline 0 & No sign or symptoms \\
1 & $0-10 \%$ infection \\
3 & $11-15 \%$ infection \\
5 & $16-25 \%$ infection \\
7 & $26-50 \%$ infection \\
9 & $>50 \%$ infection
\end{tabular}

The Per cent Disease Index was worked out as described by Mc Kinney's (1923).

PDI $=$ Sum of numerical ratings $/$ Total number of leaves observed $\times 100 /$ Maximum disease grade

Survey for collection of isolates of biocontrol agent Ampelomyces spp: The bhendi leaves showing typical

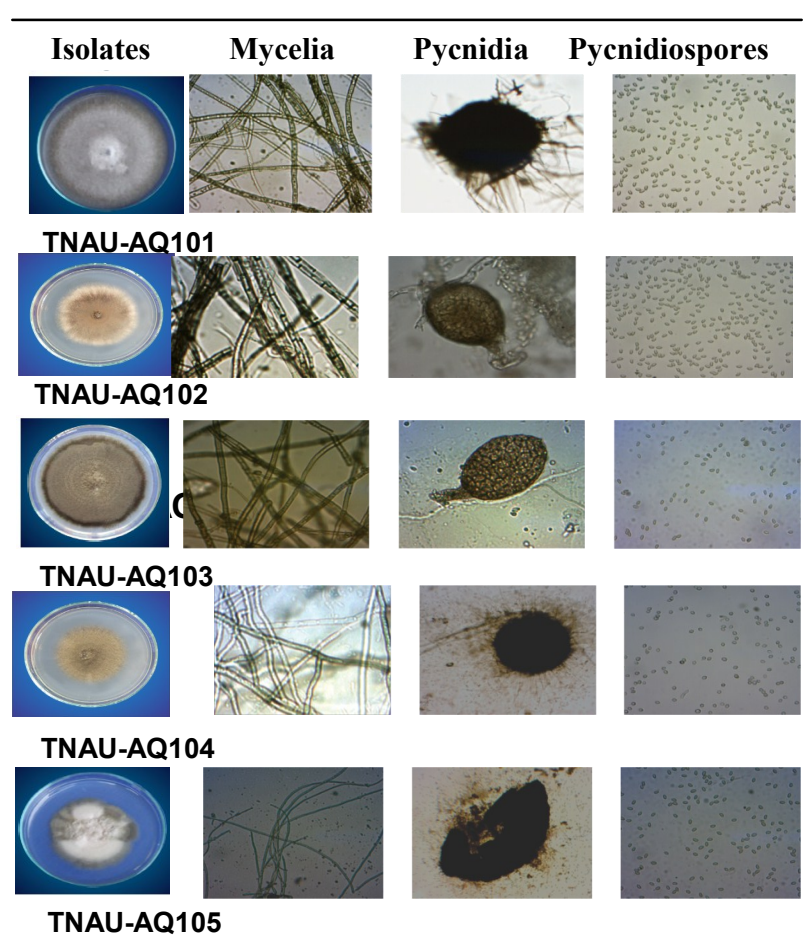

powdery mildew symptoms and hyperparasitized by Ampelomyces spp. were collected from farmer's field in different districts of Tamil Nadu. The powdery mildew infected bhendi leaves hyperparasitized by Ampelomyces spp. were collected in polythene bags and brought to the laboratory and preserved in a refrigerator at $5^{\circ} \mathrm{C}$ for further studies.

Isolation of the biocontrol agent Ampelomyces spp: Powdery mildew infected bhendi leaves parasitized by Ampelomyces spp. appearing as ash to dark brown in colour collected during the surveys were examined under the stereo microscope for the presence of pycnidia of Ampelomyces spp. The pycnidia was transferred to the Petri plates containing potato dextrose agar medium as described by Sharma (2006).

Morphological characters of different isolates of Ampelomyces spp: The different isolates of Ampelomyces spp. were grown in potato dextrose agar medium by placing a disc of the actively growing mycelium in the centre of the petridish and incubated at room temperature. Ampelomyces spp. are identified based on morphological characters that is the production of pycnidia and pycnidiospores. The morphological characters of different isolates of Ampelomyces spp. viz., spore colour, size, shape, pigmentation, zonation, colony colour, margin of the colony and topography were studied as described by Sharma (2006).

\section{RESULTS AND DISCUSSION}

Survey for the incidence of powdery mildew disease of bhendi in Tamil Nadu: The results revealed that in general the per cent disease index (PDI) of powdery

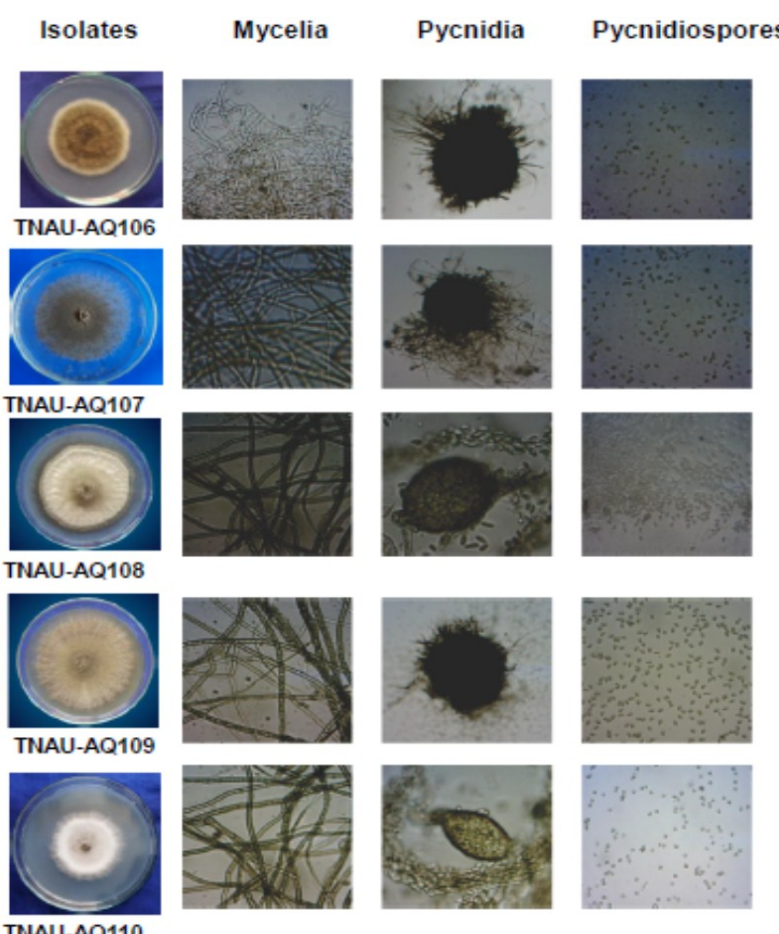

Plate 1. Morphological characters of different isolates of Ampelomyces spp. on potato dextrose agar medium. 
Table 1. Survey for the incidence of powdery mildew and collection of isolates of Ampelomyces spp. in major bhendi growing districts of Tamil Nadu.

\begin{tabular}{lllllll}
\hline S.N. & $\begin{array}{l}\text { Place } \\
\text { collection }\end{array}$ & Village/Taluk & Stage of the crop & $\begin{array}{l}\text { Variety/ } \\
\text { brid cultivated }\end{array}$ & $\begin{array}{l}\text { Mean } \\
\text { powdery mildew }\end{array}$ & $\begin{array}{c}\text { Pmpelomyces } \\
\text { spp. isolates no. }\end{array}$ \\
\hline 1 & Coimbatore & Thondamputhur & Vegetative & COBH h 1 & $63.45^{\mathrm{a}}$ & TNAU-AQ101 \\
2 & Madurai & Devankuruchi & Pod harvest & Ganga & $24.72^{\mathrm{f}}$ & TNAU-AQ102 \\
3 & Dharmapuri & Papparapatty & Fruit formation & NS 801 & $18.53^{\mathrm{g}}$ & TNAU-AQ103 \\
4 & Dindigul & Ambilikkai & Flowering & COBH h 1 & $54.27^{\mathrm{b}}$ & TNAU-AQ104 \\
5 & Trichy & Thimampatty & Fruit formation & Sakthi & $37.51^{\mathrm{d}}$ & TNAU-AQ105 \\
6 & Erode & Muthampalayam & Flowering & RASI 5 & $43.23^{\text {cd }}$ & TNAU-AQ106 \\
7 & Salem & Idappadi & Vegetative & NS 531 & $15.54^{\mathrm{h}}$ & TNAU-AQ107 \\
8 & Tirupur & Nallur & Fruit formation & COBH h 1 & $47.13^{\mathrm{c}}$ & TNAU-AQ108 \\
9 & Theni & Kovilpatti & Flowering & OH-016 & $35.47^{\mathrm{de}}$ & TNAU-AQ109 \\
10 & Cuddalore & Ramapuram & Fruit formation & Sakthi & $30.50^{\mathrm{e}}$ & TNAU-AQ110 \\
\hline
\end{tabular}

*PDI- Per cent Disease Index, * Values are means of three replications, Means followed by a common letter are not significantly different at $5 \%$ level by DMRT

Table 2. Morphological characters of different isolates of Ampelomyces spp. on potato dextrose agar medium.

\begin{tabular}{llllllll}
\hline S.N. & Isolates & Mycelium & $\begin{array}{l}\text { Topo- } \\
\text { graphy }\end{array}$ & $\begin{array}{l}\text { Colour of mature } \\
\text { colonies }\end{array}$ & Zonation & Margin & Colony growth \\
\hline 1 & TNAU-AQ101 & Septate, hyaline & Radial & Ash & Absent & Irregular & Rapid \\
2 & TNAU-AQ102 & Septate, hyaline & Appressed & Brown & Absent & Smooth & Slow \\
3 & TNAU-AQ103 & Septate, hyaline & Flat & Brownish black & Present & Wavy & Rapid \\
4 & TNAU-AQ104 & Septate, hyaline & Fluffy & Brown & Absent & Wavy & Rapid \\
5 & TNAU-AQ105 & Septate, hyaline & Fluffy & Greenish white & Absent & Irregular & Very slow \\
6 & TNAU-AQ106 & Septate, hyaline & Fluffy & Brown & Present & Smooth & Moderate \\
7 & TNAU-AQ107 & Septate, hyaline & Floccose & Brown to black & Absent & Smooth & Moderate \\
8 & TNAU-AQ108 & Septate, hyaline & Appressed & White & Present & Smooth & Rapid \\
9 & TNAU-AQ109 & Septate, hyaline & Radial & Brown & Absent & Smooth & Rapid \\
10 & TNAU-AQ110 & Septate, hyaline & Radial & White & Absent & Smooth & Moderate \\
\hline
\end{tabular}

Table 3. Pycnidial characters of different isolates of Ampelomyces spp. on potato dextrose agar medium.

\begin{tabular}{llllcc}
\hline S.N. & Pycnidia & Pycnidial size $(\boldsymbol{\mu m})$ & Pycnidiospore & Pycnidiospore size $(\boldsymbol{\mu m})$ & No. of Pycnidia \\
\hline 1 & Pyriform & $52.3 \times 32.5$ & Unicellular, hyaline, Oval & $6.6 \times 3.3$ & 11 \\
2 & Globose & $43.5 \times 24.7$ & Unicellular, hyaline, Round & $6.3 \times 3.1$ & 5 \\
3 & Globose & $72.5 \times 43.1$ & Unicellular, hyaline, oval & $6.8 \times 3.5$ & 8 \\
4 & Spherical & $50.3 \times 22.4$ & Unicellular, hyaline, Oval & $6.6 \times 3.2$ & 4 \\
5 & Ovoid & $30.5 \times 23.8$ & Unicellular, hyaline, Oval & $6.5 \times 3.3$ & 3 \\
6 & Spherical & $65.1 \times 35.7$ & Unicellular, hyaline, Round & $7.0 \times 4.1$ & 6 \\
7 & Round & $29.2 \times 22.7$ & Unicellular, hyaline, Oval & $6.2 \times 3.1$ & 7 \\
8 & Globose & $32.5 \times 24.3$ & Unicellular, hyaline, Oval & $5.8 \times 2.6$ & 6 \\
9 & Spherical & $30.8 \times 23.7$ & Unicellular, hyaline, Oval & $6.7 \times 3.3$ & 9 \\
10 & Oval & $38.9 \times 22.4$ & Unicellular, hyaline, Round & $6.6 \times 3.3$ & 4 \\
\hline
\end{tabular}

mildew ranged from 15.54 to $63.45 \%$. The maximum disease incidence of 63.45 PDI was observed at Thondamuthur village in Coimbatore district followed by 54.27 PDI at Ambilikkai village in Dindigul district. Minimum incidence of 15.54 PDI was recorded at Idappadi village in Salem district (Table 1). The present study revealed that, the incidence of powdery mildew disease showed its wide spread occurrence in almost all bhendi growing areas of Tamil Nadu.

Survey for collection of biocontrol agent Ampelomyces spp: The hyperparasite Ampelomyces spp. was isolated and the isolate number was given for each isolates collected from different districts (Table 1). In the present study, the biocontrol agent Ampelomyces spp. was isolated from the powdery mildew infected bhendi leaves by using tissue segment method. This was in accordance with the previous study conducted by Sharma (2006) and Angeli et al. (2009b) where they have isolated Ampelomyces spp. by transferring the conidia onto potato dextrose agar which was amended with $2 \%$ chloramphenicol by using tissue segment method. The fungal growth was observed and purified by hyphal tip culture technique and maintained on PDA slants at $5^{\circ} \mathrm{C}$. The same method was also reported by Liang et al. (2007). Liang et al. (2007) removed one or two pycnidia from the mildew mycelia and transferred to potato dextrose agar (PDA) supplemented with $0.5 \%$ chloramphenicol.

Morphological growth characters of different isolates of Ampelomyces spp. under in vitro conditions: The morphological characters of different isolates of Ampelomyces spp. viz., mycelium, topography, colour, margin of colonies, zonation, colony growth, pycnidial shape and size, pycnidiospore shape 
and size were studied. In general the mycelia were septate and hyaline in nature. The topography of the each isolates varied from radial, appressed, flat, fluffy and floccose. The colour of mature colonies was also varied as ash, brown and white in nature. Zonation was observed in some isolates like TNAU-AQ103, TNAUAQ106 and TNAU-AQ108. The pycnidia of different isolates of Ampelomyces spp. varied in their shape. Pycnidia were light to dark brown in colour, nonostiolate and were mostly pyriform, globose, spherical, ovoid and round in shape. In general the pycnidia measured about 29.20-65.10 × 22.40-43.10 $\mu \mathrm{m}$. This was in accordance with Liang et al. (2007) who reported that the pycnidia were pyriform to globose measuring about $36-123 \times 22-45 \mu \mathrm{m}$. Similar results were reported by Kim et al. (2009) who reported that the colour of pycnidium ranged from light brown to dark brown. Angeli et al. (2009b) revealed that the pycnidia of Ampelomyces spp. varied in shape depending upon the fungal structure in which they were formed. They were pear-shaped, spindle-shaped or nearly spherical when they were formed inside E. necator conidiophores, hyphae or chasmothecia.

Pycnidiospores were hyaline, one-celled, oval to round in shape measuring 5.8-7.0 $\times 2.6-4.1 \mu \mathrm{m}$. The number of pycnidia was found to be more in TNAU-AQ101 and TNAU-AQ103 (Table 3; Plate 1). The results agree with Kiss (2008) who reported that the conidia of Ampelomyces spp. were found to be unicellular, hyaline and guttulate in shape measuring about 11.5 to $14.5 \mu \mathrm{m}$ in length (major axis) and 2.5 to $3.5 \mu \mathrm{m}$ in width (minor axis). Liang et al. (2007) also reported that pycnidia of Ampelomyces spp. contained unicellular guttulate conidia which measured about 4.2-7.5 $\times 2$ $-3.6 \mu \mathrm{m}$. Angeli et al. (2009b) also revealed that the conidial shape of $A$. quisqualis were fusiform to ellipsoid and their size varied from 11.5 to $14.5 \mu \mathrm{m}$ in length and 2.5 to $3.5 \mu \mathrm{m}$ in width.

\section{Conclusion}

The present study revealed that, the incidence of powdery mildew disease showed its wide spread occurrence in almost all bhendi growing areas of Tamil Nadu. The per cent disease index (PDI) of powdery mildew ranged from 15.54 to $63.45 \%$. The use of $\mathrm{Am}$ pelomyces spp. is a highly elegant method of biocontrol, as the agent is specific and can expand its activity on its own and it presents no risk to the environment. The morphological characterization indicated that the mycelium is septate and hyaline in nature. The topography of different isolates varied from radial, appressed, flat, fluffy and floccose. The colour of mature colonies varied from ash to brown. Zonation was observed in some isolates. The pycnidia of different isolates of Ampelomyces spp. varied in their shape and colour. Pycnidia were light to dark brown in colour, non-ostiolate and were mostly pyriform, globose, spherical, ovoid and round in shape. In general the pycnidia measured about $29.20-65.10 \times 22.40-43.10$ $\mu \mathrm{m}$. Pycnidiospores were hyaline measuring 5.8-7.0 $\times$ 2.6-4.1 $\mu \mathrm{m}$. Incessant use of agrochemicals has many demerits such as development of resistance to pathogens, residual toxicity and environmental pollution. Hence, search for an alternative means for disease management is envisaged. Ampelomyces are the major antagonists against powdery mildew fungi which can be used as the best alternative to fungicides.

\section{REFERENCES}

Agrios, G. (2005). Plant Pathology. $5^{\text {th }}$ Eds. New York: Academic Press.

Angeli, D., Pellegrini, E and Pertot, I. (2009b). Occurrence of Erysiphe necator chasmothecia and their natural parasitism by Ampelomyces quisqualis. Phytopathology, 99:704-710.

Glawe, D. A. (2008). The powdery mildews: a review of the world's most familiar (yet poorly known) plant pathogens. Phytopathology, 46: 27

Kim, J.Y., Lee, W.H. and Kim, H.M. (2009). Physical Characteristics and Antagonistic Effect of Ampelomyces. Research in Plant Disease, 15: 209-216.

Kiss, L. (1998). Natural occurrence of Ampelomyces intracellular mycoparasites in mycelia of powdery mildew fungi. New Phytologist, 140: 709-714.

Kiss, L. (2008). Intracellular mycoparasites in action: interactions between powdery mildew fungi and Ampelomyces. British Mycological Society Symposia Series,37-52.

Liang, C., Yang, J., Kovacs, G.M., Szentivanyi, O., Xu, X. and Kiss, L. (2007). Genetic diversity of Ampelomyces mycoparasites isolated from different powdery mildew species in China inferred from analyses of rDNA ITS sequences. Fungal Diversity, 24:225-240.

Prasad, M. R., Bailey, J.A., Chandler, Jeff. St. A. (2013). Impact of Plant Spacing and Picking Interval on the Growth, Fruit Quality and Yield of Okra (Abelmoschus esculentus (L.) Moench). American Journal of Agriculture and Forestry, pp. 48-54.

Paulitz, T. C. and Belanger, R. R. (2001). Biological control in greenhouse systems. Annual Review of Phytopathology, 39: 103-133.

Ravinder Reddy, M. (1982). Evaluation of fungicides against major diseases of chilli. M. Sc.(Ag.) Thesis. Tamil Nadu Agric. Univ., Coimbatore, India.

Sharma, S. (2006). Integrated Management of Powdery Mildew Of Apple, ICAR Adhoc Research Scheme.: Final Report (2003-2006).

Sundheim, L. and Krekling, T. (1982). Host-parasite relationships of the hyperparasite Ampelomyces quisqualis and its powdery mildew host Sphaerotheca fuliginea. Journal of Phytopathology, 104: 202-210.

Yarwood, C. E. (1957). Powdery mildews. The Botanical Review, 23:235-301.

Younes, N.A. and Abo-Elyousr, K.A. (2014). Screening of some okra (Abelmoschus esculentus L.) genotypes to powdery mildew resistance and yield under agroclimatic conditions of Assiut, Egypt. International Journal of Agricultural Economics Dev., 2: 59-76. 